\title{
Who intends to enroll in entrepreneurship education? Entrepreneurial self- identity as a precursor
}

\begin{abstract}
Entrepreneurial self-identity is attracting increasing attention as a potentially relevant variable in explaining the entrepreneurial process. So far, most research treats entrepreneurial self-identity as a consequence of, or, at the most, as being developed through the start-up process. In this paper, in contrast, we analyze its role as a previous element that helps determine the entrepreneurial intention of individuals, the perceived usefulness of entrepreneurship education and, indirectly, their interest in participating in entrepreneurship education courses. Our hypotheses are tested on a sample of Italian university students and graduates $(\mathrm{N}=88)$ with no previous participation in entrepreneurship education or self-employment experience. The results clearly support the proposed model. The implications of these results, if further confirmed, are highly relevant. They indicate that there is a strong risk of self-selection bias in most entrepreneurship education evaluation studies. This is due to an element of reversed causation in which participants who already exhibit a higher entrepreneurial self-identity are more interested in entrepreneurship. At the same time, these results also suggest that professionals and public decision-makers involved in fostering entrepreneurship should pay attention to the development of this entrepreneurial self-identity in childhood and adolescence.
\end{abstract}

Keywords: entrepreneurial self-identity; entrepreneurial intention; entrepreneurship education intention 


\section{Introduction}

The concept of entrepreneurial identity has recently been attracting increasing attention (Donnellon, Ollila, \& Middleton, 2014; Duening \& Metzger, 2017). It has been argued that the identification with the specific roles associated with entrepreneurship is an important element to consider oneself as an entrepreneur (Cardon, Wincent, Singh, \& Drnovsek, 2009). Some authors stress the fact that entrepreneurship is an inherently social activity and, as such, there are relevant social aspects of the entrepreneur's self-concept that need to be taken into account (Fauchart \& Gruber, 2011). Thus, the founder's identity should play a relevant role in shaping the characteristics and profile of the new firm founded, which may in turn determine its probabilities of survival and success.

Nevertheless, the majority of this research focuses on the entrepreneurial identity that is developed when starting a new venture. In this respect, it is defined as «the constellation of claims around the founders, organization, and market opportunity of an entrepreneurial entity that gives meaning to questions of "who we are" and "what we do." " (Navis \& Glynn, 2011, p. 480). This identity is built as part of the development of the new venture and it is inherently embedded in this new firm. What is more, Down and Reveley (2004) investigate the formation of the entrepreneurial identity as an on-going process that takes place after the firm is created and when the individual is already an owner-manager.

In contrast, the development of the personal identity starts, and is determined to a substantial extent, during adolescence (Pillemer, Krensky, Kleinman, Goldsmith, \& White, 1991). A number of studies have found that personality characteristics developed at this stage are influential in predicting entrepreneurial behavior over twenty years later (Obschonka, Goethner, Silbereisen, \& Cantner, 2012; Schoon \& Duckworth, 2012). For 
this reason, it is important to understand the role that early personal-identity construction plays in the subsequent development of entrepreneurial interest and behavior. This early formation of a personal identity that is pro-entrepreneurial should affect the selection of educational and occupational trajectories.

Therefore, in this paper we focus on the entrepreneurial identity as a previous element that may contribute to individuals choosing an entrepreneurial career path. In particular, an entrepreneurial self-identity developed during adolescence may spark the interest toward entrepreneurship education as a means to increase the personal knowledge and skills needed to become an entrepreneur. From this perspective, an entrepreneurial selfconcept would be one of the key initial elements conforming the decision to enter into the entrepreneurial career path.

In this vein, an increasing number of contributions focus on the relationship between the entrepreneurial identity and entrepreneurship education and learning (Donnellon et al., 2014; Duening \& Metzger, 2017; Mueller \& Anderson, 2014). Most research so far has analyzed the relationship from entrepreneurship education to the formation of an entrepreneurial identity (Donnellon et al., 2014). It tends to agree that an action-based entrepreneurship education approach is more effective to develop the entrepreneurial selfconcept in the participants. In this view, the construction of an entrepreneurial identity is intertwined with the development of entrepreneurial competences (Mets, Kozlinska, \& Raudsaar, 2017). Thus, at least at the university level, action-based or competence-based pedagogies should be preferred (Nabi, Liñán, Fayolle, Krueger, \& Walmsley, 2017).

Our approach, in turn, focuses on the potential reversed causality that may start from a pre-existing entrepreneurial self-identity. That is, those university students having developed an entrepreneurial self-concept during adolescence would be more interested 
in entrepreneurship and would, therefore, have a higher likelihood of enrolling in entrepreneurship education.

To analyze this relationship, we identify the entrepreneurial intention as a key element signposting the existence of a clear entrepreneurial career interest. The entrepreneurial intention is one of the most prevailing constructs to understand the pre-launching stages of the entrepreneurial process. According to this, the intention to start a venture is a key precursor of actual behavior(Krueger, Reilly, \& Carsrud, 2000). Several studies have confirmed the applicability of this theory to entrepreneurship (Kautonen, van Gelderen, \& Fink, 2015; Kautonen, Van Gelderen, \& Tornikoski, 2013; Liñán \& Rodríguez-Cohard, 2015).

As Ireland and Webb (2007, p. 916) put forward, “entrepreneurship is a process of identity construction". This process involves the elaboration of self-narratives that create a coherent and distinct identity. This is done through a process of acculturation and assimilation (Duening, 2017, p. 10). Thus, we argue that the development of an entrepreneurial personal identity in adolescence is a key element in the formation of enterprising individuals. They may decide to become entrepreneurs (self-employed owner-managers of commercial ventures) or to develop their entrepreneurial competences in alternative professional careers (non-commercial endeavors, environmental or community projects, etc.). That is, the entrepreneurial activity is seen as part of the wider environment -commercial, but also natural, social and cultural (Ahmad \& Seymour, 2008). This view opens the door to interpretations other than those exclusively based on business/economic value creation (Hytti, 2008; Komarkova, Conrads, \& Collado, 2015). Entrepreneurship includes not only new venture creation, but can also been considered as a major social force (Sarasvathy \& Venkataraman, 2011). 
Overall, then, an entrepreneurial self-identity may not be enough in itself to be a successful entrepreneur, but it will probably constitute a necessary condition. In this particular study, we focus on its role as predicting further intention to participate in entrepreneurship education. To do so, the next section reviews the relevant literature to elaborate on the concept of entrepreneurial identity. It also develops our research hypotheses. The methodology section describes the design of the empirical analysis and the sample's characteristics. This is followed by the presentation of the results. Finally, the paper ends with two sections devoted, respectively, to the discussion of the results and to summarizing the main conclusions derived from the article.

\section{Literature review}

\section{The entrepreneurial identity}

In social psychology, «self-identity refers to salient and enduring aspects of one's selfperception» (Rise, Sheeran, \& Hukkelberg, 2010, p. 1087). That is, it represents the replies to the question "who am I?", which describe oneself as pertaining to one or several socially meaningful categories. Individuals will typically adhere to several simultaneous identities, which altogether form a composite global or super-ordinate identity (Newbery, Lean, Moizer, \& Haddoud, 2018; Shepherd \& Haynie, 2009). Thus, individuals have several micro-identities that will be enacted contingent upon the specific social situation that they face (Newbery et al., 2018).

The construction of identity takes place in the emergence of social and temporal memories of life, along with an autobiographical reasoning about successive experiences, contexts and people encountered (Williams, Conway, \& Cohen, 2007). People shape their identity by telling the story of their own lives. In this sense, narrative plays a central role in the 
construction of identity because, through the story, persons "invent" themselves and give meaning to their existence (Ricœur, 1990).

Building the narration of oneself means finding a guiding thread that offers meaning to past experience by relating it to the present and projecting it into the future (Williams et al., 2007). The narration fulfills a mediating function between the different times lived and the present moment. Educational events are part of life stories and shape our personal identity. Thus, the investigation of how educational experiences contribute to the formation of the personal identity is highly relevant (Bernal, 2014).

To deepen our knowledge about the formation of the personal identity, we have to attend to the formation of autobiographical recollections in that memory (Williams et al., 2007). In particular, experiences experienced as emotional are best remembered, and have a more important role in the construction of the personal identity (Holland \& Kensinger, 2010). School experiences do not escape this argument.

The period of basic education and schooling usually ranges from three to sixteen years of age. This involves a path or educational trajectory where the subject undergoes profound changes, based on physical growth, cognitive and intellectual development, progress in social knowledge, development of norms and values, and affective development (Bernal, 2014). The life experiences lived by the individual during that period will have a most prominent effect in the configuration of what the person is; i.e., the multifaceted identities comprising their personality. In this process, the great number of hours and years spent in school, along with the variety of relationships established among its members, play a main role in understanding the gradual transformations that are chiseling the features and constructing the subject's personal identity from early childhood (Pillemer et al., 1991).

During that period, individuals gain awareness about entrepreneurship through their vicarious contact with, and observation of, role models around them (family or peer group 
members), as well as through the information received from social media (Swail, Down, \& Kautonen, 2014). At this early stage, the impression the individual has about what an entrepreneur is and what they do is based on a mix of observed behaviors (Newbery et al., 2018). The individual identifies these roles as comprising the entrepreneurial identity, and will compare this general impression with the perspective taken toward oneself when assuming those roles of others (Stets \& Burke, 2000). These others may be specific (my father, or mother), or generalized (the fathers, the mothers). Through this identification process, the meanings and expectations associated with one specific categorization (identity) are incorporated into the self. That is, one forms a set of identity standards that guide the identity-relevant behaviors (Rise et al., 2010).

The different self-identities that comprise the overall global identity are derived from socially constructed and accepted types of persons (categories). They are accepted by the individual as descriptive of herself or himself. Thus, the self-identity represents a sociallydefined influence (Hagger \& Chatzisarantis, 2006). Self-identity is a form of socialidentity (Stets \& Burke, 2000), in the sense that it is derived from the process of socialization and observation of the different social groups (categories).

Difference in identity-related beliefs are relevant in explaining the differences in educational and occupational choices (Eccles, 2009). An occupational self-concept is «the conception of self-perceived attributes that an individual considers relevant to work roles» (Savickas, 2002, p. 163). Each person has distinct components of the self; that is, a different collection of identities reflecting the different roles the person fulfills in the social structure (Terry, Hogg, \& White, 1999). In the case of entrepreneurship, the entrepreneurial self-identity refers to the social roles that make up and have to be fulfilled to be part of the entrepreneurship occupational category (Obschonka, Silbereisen, Cantner, \& Goethner, 2015). 
The configuration of the personal identity, understood as the agency of the subject, is intimately related to the motivational and intentional processes. These processes confer energy and action patterns, facilitating the realization of personal aspirations, tasks and projects (Cantor, 1994; Emmons, 1989). Being and feeling agency implies not only initiating actions and knowing how to carry them out, but also managing self-emotions for a consistent execution of our actions. Thus, having a particular role identity implies that one is motivated to act in a way that fulfills the expectations of this role. This is of particular relevance in the occupational field, and in particular in the selection of educational or career paths. Individuals will seek to explore career options related to their identity -in this case entrepreneurship- (Newbery et al., 2018), and will thus be motivated to engage in specialized entrepreneurship education.

As described below, individuals with an entrepreneurial self-identity developed during adolescence will exhibit a higher entrepreneurial intention and will also perceive that entrepreneurship education is a useful means to develop the knowledge and skills needed to become an entrepreneur.

\section{Self-identity and entrepreneurial intention}

The entrepreneurial behavior is most frequently considered as intentional (Kautonen et al., 2015; Krueger et al., 2000; Schlaegel \& Koenig, 2013). Nevertheless, some scholars have argued that the entrepreneurial self-identity (ESI) should be taken into account in order to more comprehensively understand the entrepreneurial intention (Rise et al., 2010). The relationship between self-identity and behavior is significant and direct. Roles

represent expectations of what constitutes appropriate behaviors and, therefore, performing them is a validation of the status as a role member (Terry et al., 1999). 
The self-identity construct has been conceptualized as an independent predictor of behavioral intentions (Carter, 2013; Rise et al., 2010). One acts in accordance with one's self-identity for self-verification reasons (Biddle et al., 1985). That is, people are motivated to act because they retain and affirm the sense of self and identity, in order to be consistent with their identity standard (Stets \& Burke, 2000). By this account, when the social categorization including this specific identity is activated, the person will feel inclined to behave so as to maintain consistency with the meanings held in the identity standards. People tend to confirm and support their self-concept by acting in accordance with their salient self-identity (Obschonka et al., 2012). Thus, self-identity will be relevant in predicting intentions (Rise et al., 2010).

Entrepreneurial behavior is relatively complex, involving longer time lags and uncertainty, together with the need to coordinate relevant resources that may not be under the entrepreneur's direct control (S A Shane \& Venkataraman, 2000). For these reasons, the influence of self-identity on behavior may not be evident. However, to the extent that it represents a vocational behavior, the importance of identity activation may be even greater, since vocation is one of the major channels that allow people to live out their selfconcept (Super, 1963). Career choices are fundamentally determined by the possibility that the chosen job allows enduring self-verification (Swann Jr., Rentfrow, \& Guinn, 2002). As Krueger (2007) suggests, entrepreneurial self-identity constitutes the deep beliefs that are manifested through entrepreneurial activity. Thus, the motivational root of self-identity is self-verification, which is most relevant in the formation of the entrepreneurial career intention (Rise et al., 2010).

From an empirical point of view, studies on the relation between self-identity and behavioral intention have collected mixed results ranging from an apparent lack of effect (Fekadu \& Kraft, 2002) to statistically significant results showing that self-identity has a 
strong effect on intention (Nigbur, Lyons, \& Uzzell, 2010; Terry et al., 1999). In their meta-analysis, Rise et al.(2010) find self-identity to have a statistically relevant influence on behavioral intention, which stretched over a wide range of behavioral domains.

Based on this reasoning, we propose the following hypothesis:

Hypothesis 1: An entrepreneurial self-identity is positively linked to the entrepreneurial intention.

\section{Self-identity and perceived usefulness of entrepreneurship education}

The entrepreneurial self-identity will motivate an interest in entrepreneurship as a career path, since the person will seek to reinforce his/her perceived self-identity (Newbery et al., 2018). To do so, he/she will need to gain additional (deeper) knowledge and understanding of the different roles involved in entrepreneurship (Hoang \& Gimeno, 2010). Younger individuals tend to lack entrepreneurial experience. The comprehension that they have of role contents is likely unsophisticated and broad (Farmer, Yao, \& KungMcintyre, 2011). For them to realize their entrepreneurial identity aspirations, they have to take each opportunity to learn what to do to be entrepreneurs.

That is, people exhibiting a high entrepreneurial self-identity will try to gain additional knowledge and master the role-behaviors associated with entrepreneurship. Career decisions tend to be clearly anchored within self-beliefs (Lent, Brown, \& Hackett, 1994). When a person holding strong entrepreneurial self-identity is able to realize that aspiration, this generates positive feelings in the potential entrepreneur (Cardon et al., 2009; Farmer et al., 2011). This aspiration will contribute to increasing the commitment and effort the person is willing to employ, leading to entrepreneurial engagement and persistence (Cardon et al., 2009; Scott A Shane, Locke, \& Collins, 2003). 
In the case of university students, they are in an educational stage clearly focused on the development of specialized knowledge and skills that should be useful in their subsequent professional careers. In this sense, they will recognize the relevance and usefulness of specially-focused entrepreneurship-related education as a form to gain a more thorough and realistic view of entrepreneurial roles (Krueger, 2003).

Thus, we propose the following hypothesis:

Hypothesis 2: An entrepreneurial self-identity will be positively related to the perceived usefulness of entrepreneurship education.

\section{Entrepreneurial intention, perceived usefulness and entrepreneurship education}

The entrepreneurial intention is frequently defined as a goal intention (Adam \& Fayolle, 2015). This is because becoming an entrepreneur is not a simple one-time event. In turn, it involves considerable time-lags and numerous specific tasks that have to be completed before the goal is achieved. It also implies considerable uncertainty, since it depends on a host of contextual and intra-personal elements (van Gelderen, Kautonen, Wincent, \& Biniari, 2017). In this sense, according to Gollwitzer (1999), goal-setting is a predecisional phase in which the desired final outcome is decided. This first stage is followed by a second one, which is post-decisional and pre-actional, in the sense that the individual has to decide which is the most practical or effective action plan to achieve the chosen goal (Adam \& Fayolle, 2015; Gollwitzer, 1999; van Gelderen et al., 2017).

University students will see becoming an entrepreneur as a goal that is most probably distant in time, since they will tend to postpone its achievement until after they have finished their studies and possibly gained some labor experience (Åstebro, Bazzazian, \& Braguinsky, 2012). Meanwhile, those students with a high entrepreneurial intention will 
try to take advantage of any opportunity to accumulate the knowledge and skills they think they will need. In this sense, their action plans to eventually become an entrepreneur will involve the intention to enroll in the entrepreneurship education courses that are available.

Nevertheless, the final decision to enroll in this course is dependent on a number of variables, including practical aspects (schedule, assessment method, etc.) but also the perceived usefulness (Becker \& Gibson, 1998). If the course is perceived as potentially contributing to the development of the knowledge and skills needed to become an entrepreneur, the student will have a higher intention of taking the course.

Thus, we propose the following hypotheses:

Hypothesis 3: A higher entrepreneurial intention will be positively related to the entrepreneurship education intention.

Hypothesis 4: A higher perceived usefulness of entrepreneurship education will be positively related to the entrepreneurship education intention.

Figure 1. Research model and hypotheses

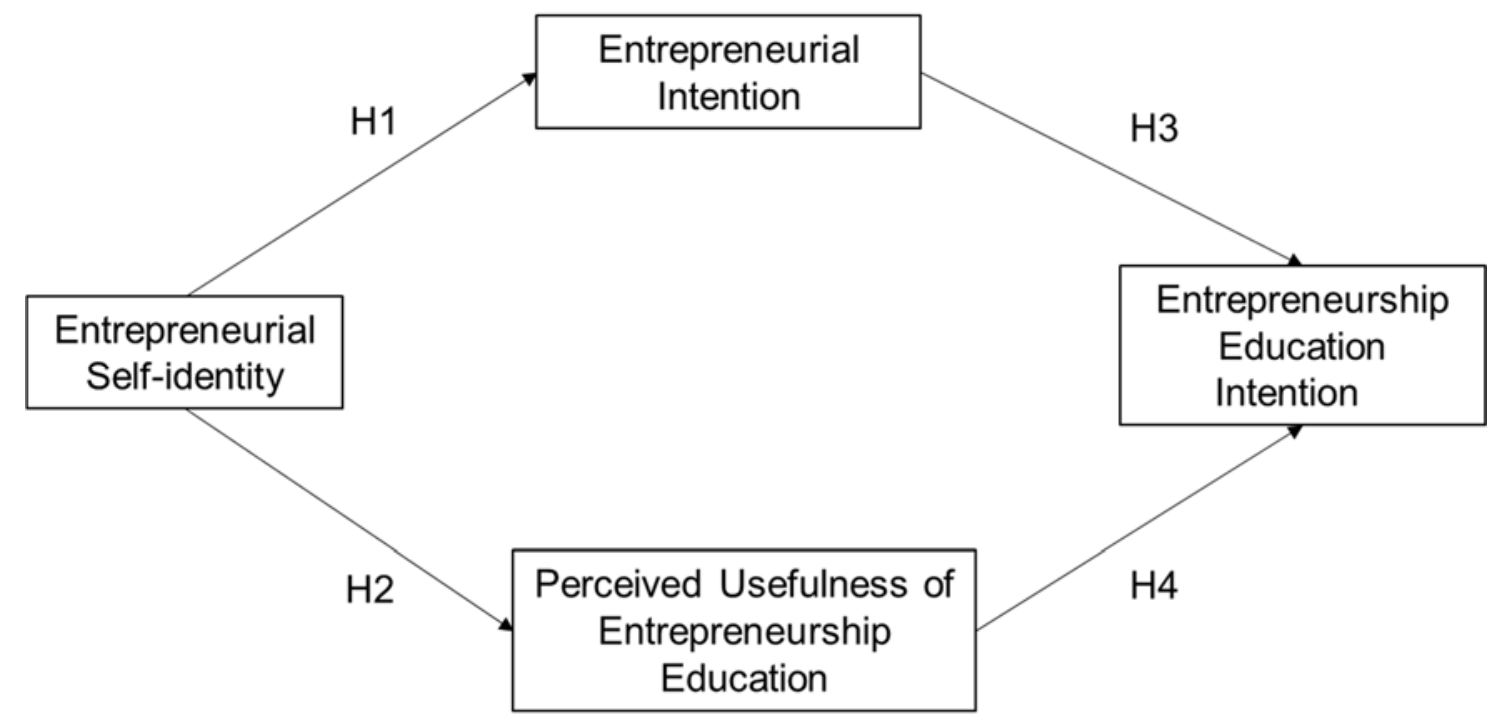


These four hypotheses are presented in Figure 1 and constitute our research model. In it, the entrepreneurial self-identity developed before participation in the entrepreneurship education program explains the level of entrepreneurial intention, as well as the perceived usefulness of the program. These latter variables, in turn, are influential in the intention to participate in the entrepreneurship education course.

\section{Methodology}

\section{Sample}

The research study was carried out in a public university in the south of Italy. Students and recent graduates registered at the Placement Service of a University Department were approached. Of the total of 106 registered subjects, 89 participated in the study. One of them was excluded as having entrepreneurial experience. The final sample is made up of 88 college students $(60.2 \%)$ and graduates $(39.8 \%)$, with $35 \%$ males and $65 \%$ females. This represents $83 \%$ of the total registered subjects. The great majority of respondents are less than 29 years old in this sample (81\%), and only $4.5 \%$ are over thirty-five years of age. Most of them (87.5\%) were unemployed or searching for the first job at the time of the questionnaire's administration. The respondents had not participated in any entrepreneurship education course before, nor had they had self-employment experience.

\section{Measures}

In order to test the hypothesized research model, a questionnaire divided into five sections has been developed. The first four sections measured the following constructs: entrepreneurial self-identity, entrepreneurial intention, perceived usefulness of entrepreneurship education and entrepreneurship education intention. The last section 
explored some demographic data, such as age, university course, previous work experiences, etc. The 18 items used for the four central constructs have been measured with a seven-point Likert-type scale, ranging from 1 (do not agree at all) to 7 (absolutely agree). All of these items have been adapted by Ceresia and Mendola (2017), based on well-established and validated measures, as detailed below.

The first section measures the entrepreneurial intention. The scale has been adapted from the entrepreneurial intention subscale of the Entrepreneurial Intention Questionnaire (EIQ) developed by Liñán and Chen (2009). The subjects were asked to indicate how much they agreed with six statements. An example item is: "I'll do everything to become an entrepreneur".

The second section measures the entrepreneurial self-identity. The scale has been adapted from the Self-Identity Scale developed by Terry et al. (1999). The respondents were asked to indicate how much they agreed with the statements regarding the consideration about them. An example item is the following: "I consider myself as having entrepreneurial characteristics".

The third section measures the perceived usefulness of entrepreneurship education. The scale has been developed based on Lu, Zhou and Wang (2009). The respondents were asked to indicate how much they agreed with five statements, after reading a short description about a well-prepared entrepreneurial course. For example, they had to answer to the following item: "The entrepreneurial course will allow me to have all the instruments and knowledge needed to become an entrepreneur".

The fourth section measures the entrepreneurship education intention. The three items scale has also been adapted from the EIQ questionnaire (Liñán \& Chen, 2009). The respondents were asked to indicate their level of agreement with statements about their volition to enroll in an entrepreneurship course in the near future. An example item is the 
following: "I'm firmly determined to enroll in an entrepreneurship course in the near future".

As with any self-reported measures, the risk of common method bias is always present (Conway \& Lance, 2010). Nevertheless, a number of steps were taken to prevent it, as suggested by Podsakoff, MacKenzie, Lee, \& Podsakoff (2003). The participants were reassured that their responses were to remain anonymous, that they would only be used for the purposes of the research and that there were no right or wrong answers. These measures should have served to prevent common method bias and avoid the negative consequences derived from its occurrence (Conway \& Lance, 2010).

\section{Procedures}

The subjects were asked to participate through an online questionnaire. Those respondents who indicated that they had participated in previous entrepreneurship courses were dropped from the analysis. The data has been analyzed using IBM's SPSS software v.23 to produce descriptive statistics and a Cronbach's Alpha analysis of the four questionnaire factors.

Amos v.23 software has been used to test the adequacy of the structural equation model and examine the hypothesized relationships. Despite the relatively small sample size, given that only 4 latent variables are being considered, this should provide a valid initial test of the model (Sideridis, Simos, Papanicolaou, \& Fletcher, 2014). The hypothesized structural equation model was compared with the empirical data, allowing each item to saturate on a single factor and by setting to zero all other factor loadings. Covariance between the factors were free parameters. The model's goodness of fit was verified by the following indices: $\chi^{2}$; the ratio between $\chi^{2}$ and the degrees of freedom of the model 
$\left(\chi^{2} / \mathrm{df}\right)$; the Tucker-Lewis Index -TLI (Bentler \& Bonnett, 1980); the Comparative Fit Index -CFI (Bentler, 1990) and the Root Mean Square Error of Approximation (RMSEA).

Based on the analysis of skewness and kurtosis statistics, the variables were normally distributed. We also checked for the existence of multicollinearity between the model variables. The collinearity statistics were within the accepted limits (tolerance between .351 and .625; variance inflation factor -VIF- between 1.599 and 2.906) (Bryman \& Cramer, 2004; Field, 2005). Additionally, a confirmatory factor analysis was run to confirm the model structure and discriminant validity between the variables. The fit was satisfactory $\left(\chi^{2}(132, \mathrm{~N}=88)=302.491, \mathrm{p}<.000, \mathrm{TLI}=.905, \mathrm{CFI}=.911\right.$ and RMSEA $=.116)$.

\section{Results}

Table 1 presents the means, standard deviations, Cronbach's Alphas and correlation matrix for the four research constructs. The average level of entrepreneurial self-identity is below the scale's central score (4), indicating that the majority of respondents do not see themselves as entrepreneurs. The entrepreneurial intention is only slightly over the central point, in line with the low level of entrepreneurial self-identity. In turn, the perceived usefulness and the intention to enroll in entrepreneurship education are clearly favorable. The reliability levels are high and the correlations among the constructs are moderate to strong. In particular, an entrepreneurial self-identity is strongly related to exhibiting entrepreneurial intentions. 
Table 1. Means, Standard Deviations, Cronbach's Alphas and correlations of the four questionnaire constructs

\begin{tabular}{|c|c|c|c|c|c|c|}
\hline QUESTIONNAIRE FACTORS & CA & MEAN & SD & ESI & EI & $\mathbf{P U}$ \\
\hline Entrepreneurial Self-Identity (ESI) & .85 & 3.25 & 1.40 & & & \\
\hline Entrepreneurial Intention (EI) & .97 & 4.24 & 1.60 & $.775 *$ & & \\
\hline $\begin{array}{l}\text { Perceived Usefulness of } \\
\text { Entrepreneurship Education (PU) }\end{array}$ & .97 & 4.90 & 1.52 & $.501^{*}$ & $.522 *$ & \\
\hline $\begin{array}{l}\text { Entrepreneurship Education } \\
\text { Intention (EEI) }\end{array}$ & .96 & 4.80 & 1.73 & $.503 *$ & $.582 *$ & $.524 *$ \\
\hline
\end{tabular}

Note: * Correlation is significant at the 0.01 level (2-tailed test). CA $=$ Cronbach's Alpha.

The research model was tested using structural equation techniques. The results are summarized in Figure 2. As may clearly be seen, all four path coefficients are moderate to strong and statistically different from zero. Thus, our hypotheses are supported.

Table 2. Goodness of fit indexes for the hypothesized structural equation model

\begin{tabular}{cccccccc}
\hline Model & $\chi^{2}$ & $\mathrm{df}$ & $\chi^{2} / \mathrm{df}$ & TLI & CFI & RMSEA & $\mathrm{p}$ \\
\hline $\mathrm{A}$ & 211,452 & 131 & 1,614 & .951 & .958 & .08 & .000 \\
\hline
\end{tabular}


Figure 2. Path diagram for the hypothesized structural equation model

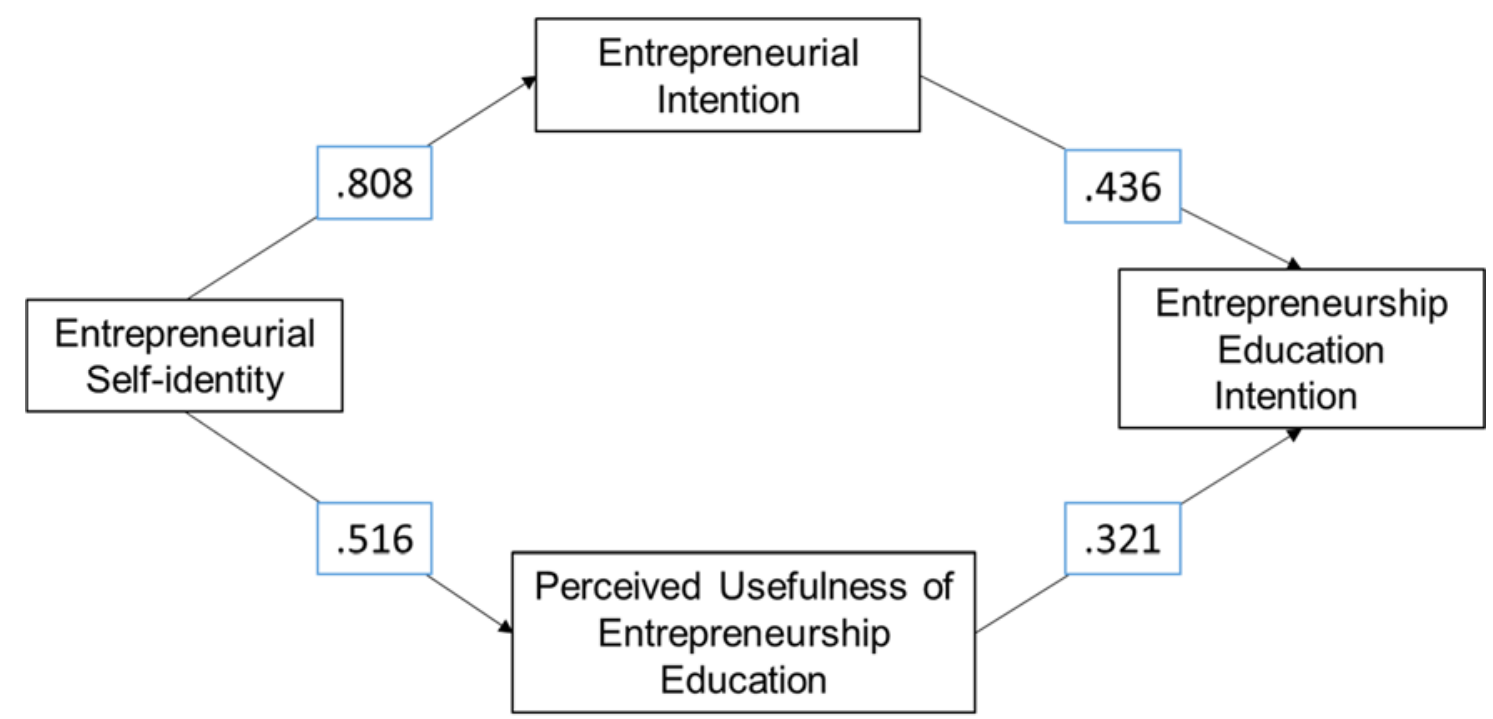

Note: all path coefficients are highly significant $(\mathrm{p}<.001)$.

Table 2 presents the goodness of fit indexes for the model. As may be seen, the TLI (.951) and CFI (.958) fit indexes for the proposed model were adequate, as is the case for the $\chi^{2} / \mathrm{df}$ ratio and the RMSEA level (Hair, Hult, Ringle, \& Sarstedt, 2014). The analysis of the standardized estimates of path coefficients reveals that the estimated parameters are substantial (range between .321 and .808) and the standard errors are acceptable (range between .10 and .15).

Finally, we tested whether the four different subjects' employment status (unemployed, searching for their first job, employee and freelance) could affect the entrepreneurial selfidentity. A one-way between subject ANOVA has been performed. The result shows that the effect of different employment status on entrepreneurial self-identity was not significant $[\mathrm{F}(3,84)=.214, \mathrm{p}=.887]$. 


\section{Discussion}

Contrary to several studies analyzing the role of entrepreneurship education in the development of an entrepreneurial self-identity (Donnellon et al., 2014), in this paper we argue that the entrepreneurial self-identity is an important precursor of subsequent interest in entrepreneurship and entrepreneurship-related education. Our results are clearly compatible with this argument. The entrepreneurial self-identity is associated with a higher entrepreneurial intention and with a greater perceived usefulness of entrepreneurship education. Not surprisingly, these latter variables in turn significantly relate to a higher intention to enroll in an entrepreneurship education course.

Of course, the entrepreneurial self-identity evolves over time as the individual matures and acquires additional experience. The perception about the role categories associated with entrepreneurship at the age of, say, 15 will not be the same as the perception when the individual is 25 or 35 years old. Our argument is, then, that an initial entrepreneurial self-identity (underdeveloped as it may be) will be very relevant in orienting the personal steps toward this specific career path. But, at the same time, the specific steps taken will shape and modify the entrepreneurial self-identity to make it more comprehensive and developed. This is in agreement with the views of Donnellon et al. (2014) and Simon and Reveley (2004), who consider self-identity as developed "through" entrepreneurship. In this research, therefore, we focus on the initial stages in personal identity construction, which starts in childhood and conditions subsequent career selections very early in the process.

We have tested these relations on a sample of university students and recent graduates. The majority of them were undergraduates with no labor experience and none of them had attended any entrepreneurship education program or course. In addition, the result of the ANOVA confirmed that the employment status had no influence on entrepreneurial 
self-identity. Therefore, those exhibiting a high entrepreneurial self-identity will have most probably developed it as a consequence of personal experiences gained during study, working or leisure time in their adolescence. In this sense, this is probably one of the reasons behind the so-called "self-selection bias" found in several entrepreneurship education studies (Bae, Qian, Miao, \& Fiet, 2014; Noel, 2002). Bae et al. (2014) investigated the relationship between entrepreneurship education and entrepreneurial intention. They verified that the post-education entrepreneurial intentions are affected by pre-education entrepreneurial intentions much more than they are by the entrepreneurship education itself. This made them talk about the existence of a "reversed causation".

In previous research, the relationship between entrepreneurship education and entrepreneurship intention has mainly been analyzed on subjects enrolled in entrepreneurship courses. Thus, this result could be reasonably explained by the assumption that an individual genuinely interested in undertaking an entrepreneur's career will more likely enroll in an entrepreneurship course than an individual who does not manifest such an interest (Kolvereid \& Moen, 1997). The consequence of this is that the subjects of these research works have not been randomly selected. Reversed causation also clarifies that the small and positive relationship between entrepreneurship education and post-education entrepreneurial intentions is -most probably- the result of a selfselection bias triggered by the trainees themselves as a result of their choice to attend an entrepreneurship course. From this point of view, entrepreneurial self-identity represents a key prerequisite for an individual to develop a pre-education entrepreneurial intention and, as a consequence, the intention of attending an entrepreneurship education program.

\section{Implications}


Our study has a number of relevant implications. In the first place, it strongly indicates that the initial self-perceptions of participants in entrepreneurship education programs are highly important. The self-selection bias adds difficulty to the evaluation of entrepreneurship education courses, since the direct comparison of participants in the program with non-participants -even if the former exhibit a higher entrepreneurial intention or higher start-up rates- is no proof that the program is effective. They probably had a more developed entrepreneurial self-identity and -through it- a higher entrepreneurial intention before the course, and this made them self-select themselves for the course.

A more developed evaluation approach is required, including pre- and post- measures and -ideally- a control group for comparison purposes (Nabi et al., 2017). Based on our results, controlling for the self-selection of more entrepreneurial students for entrepreneurship education programs becomes essential. Educators have to be aware of this and tailor the programs to the characteristics of the participants.

On the other hand, these results represent a strong basis for the careful design and implementation of interventions in the primary and secondary school levels (Bernal \& Liñán, 2018). This pre-university entrepreneurship education should be focused on the development of entrepreneurial self-identities among children and teenagers. The specific objectives and contents to be included in these courses are well beyond the scope of our paper. However, we doubt that their main focus should be on the specific instruments and techniques to start a venture (business plan, business model canvas, etc.). In turn, an approach based on the identification and ability to get acquainted with and understand the different entrepreneurial roles is probably more promising. For instance, entrepreneurs have to identify and evaluate opportunities. High-school students should know this and 
possibly see examples of how this was done in some cases. But they may not need to master specific opportunity-evaluation techniques.

Some authors argue that it is important to stress the positive contribution entrepreneurs make to society. Duening and Metzger (2017) propose to focus on what they call "the entrepreneurial virtues". In this sense, we believe that the promotion of the personal values of initiative, autonomy and creativity will be effective in making the students interested in the entrepreneurship career path (Bernal \& Liñán, 2018).

\section{Limitations and future research lines}

This study, as any other, suffers from a number of limitations. Firstly, the sample size is relatively small, and the respondents are students from a single university. Therefore, the generalizability of the results cannot be taken for granted. Nevertheless, the hypotheses are strongly supported, despite the sample size. Secondly, the research has been designed as a cross-sectional study. In this type of analyses, causality cannot be proved, in contrast to the possibilities offered by a longitudinal study. Some steps were taken, though, to compensate for this limitation. It was ensured that the respondents had not participated in any entrepreneurship education initiative before the data collection. Similarly, they had not had any self-employment experience. In this way, the possibility that their entrepreneurial self-identity or entrepreneurial intention levels were the consequence of previous entrepreneurship-related education or experience was minimized.

From these limitations, some obvious avenues for future research emerge. Regarding the issue of generalizability, additional research could be carried out to test this model on larger samples from diverse origins, educational levels, or with different family and educational backgrounds. With regard to the second limitation, a longitudinal design is 
clearly adequate. This would not only add rigorousness, but it would also allow a study of the change in entrepreneurial self-identity throughout the different life and/or educational stages.

In particular, we have argued in his paper that the personal self-identity may be developed at a relatively early stage, during childhood and adolescence. Although there is a considerable literature to support this assertion, the specific formation of an entrepreneurial self-identity is under-researched. What kind of experiences at this age are more influential to develop such a self-identity? What educational interventions in primary and secondary education could be more effective in this respect? New research on this area could help answer these questions.

\section{Conclusion}

In this paper, we have reversed the most common point of view in recent literature about the relationship between entrepreneurship education and entrepreneurial self-identity. While most research argues for entrepreneurship education as the cause, we argue the opposite. An entrepreneurial self-identity may exist before having any professional entrepreneurial experience, or taking any entrepreneurship education courses. And this will be most relevant in raising the entrepreneurial intention as well as the intention to participate in entrepreneurship education. How may this entrepreneurial self-identity be developed? This is beyond the scope of our paper, but specific actions in primary and secondary education will probably be most relevant in this respect.

\section{References}

Adam, A. F., \& Fayolle, A. (2015). Bridging the entrepreneurial intention-behaviour 
gap: the role of commitment and implementation intention . International Journal of Entrepreneurship and Small Business, 25(1), 36-54.

Ahmad, N. H., \& Seymour, R. (2008). Defining Entrepreneurial Activity Definitions Supporting Frameworks for Data Collection. Paris.

Åstebro, T., Bazzazian, N., \& Braguinsky, S. (2012). Startups by recent university graduates and their faculty: Implications for university entrepreneurship policy. Research Policy, 41(4), 663-677.

Bae, T. J., Qian, S., Miao, C., \& Fiet, J. O. (2014). The Relationship Between Entrepreneurship Education and Entrepreneurial Intentions: A Meta-Analytic Review. Entrepreneurship Theory and Practice, 38(2), 217-254.

Becker, E. A., \& Gibson, C. C. (1998). Fishbein and Ajzen's theory of reasoned action: Accurate prediction of behavioral intentions for enrolling in distance education courses. Adult Education Quarterly, 49(1), 43-55. https://doi.org/10.1177/074171369804900105

Bentler, P. M. (1990). Comparative fit indexes in structural models. Psychological Bulletin, 107, 238-246.

Bentler, P. M., \& Bonnett, D. G. (1980). Significance tests and goodness-of-fit in analysis of covariance structures. Psychological Bulletin, 88(3), 588-606. https://doi.org/10.1037/0033-2909.88.3.588

Bernal, A. (2014). Competencia emprendedora e identidad personal. Una investigación exploratoria con estudiantes de educación secundaria obligatoria. Revista de Educacion, (363), 384-411.

Bernal, A., \& Liñán, F. (2018). The personal dimension of an entrepreneurial competence: An approach from the Spanish basic education. In A. Fayolle (Ed.), A 
Research Agenda for Entrepreneurship Education. Cheltenham, U.K. ; Northampton, MA: Edward Elgar Pub.

Biddle, B. J., Bank, B. J., Anderson, D. S., Hauge, R., Keats, D. M., Keats, J. A., ... Valantin, S. (1985). Social influence, self-refernt identity labels, and behavior. Sociological Quarterly, 26(2), 159-185. https://doi.org/10.1111/j.15338525.1985.tb00221.x

Bryman, A., \& Cramer, D. (2004). Quantitative data analysis with SPSS 12 and 13: a guide for social scientists. London: Routledge.

Cantor, N. (1994). Life task problem solving: Situational affordances and personal needs. Personality and Social Psychology Bulletin, 20(3), 235-243. https://doi.org/10.1177/0146167294203001

Cardon, M. S., Wincent, J., Singh, J., \& Drnovsek, M. (2009). The nature and experience of entrepreneurial passion. Academy of Management Review, 34(3), 511-532. https://doi.org/10.5465/AMR.2009.40633190

Carter, M. J. (2013). Advancing Identity Theory. Social Psychology Quarterly, 76(3), 203-223. https://doi.org/10.1177/0190272513493095

Ceresia, F., \& Mendola, C. (2017). Psychometric properties of a questionnaire measuring the antecedents of entrepreneurship education intention. In The European Proceedings of Social \& Behavioural Sciences (pp. 742-754). https://doi.org/10.15405/epsbs.2017.10.71

Conway, J. M., \& Lance, C. E. (2010). What Reviewers Should Expect from Authors Regarding Common Method Bias in Organizational Research. Journal of Business and Psychology, 25(3), 325-334.

Donnellon, A., Ollila, S., \& Middleton, K. W. (2014). Constructing entrepreneurial 
identity in entrepreneurship education. International Journal of Management Education, 12(3), 490-499.

Down, S., \& Reveley, J. (2004). Generational Encounters and the Social Formation of Entrepreneurial Identity: "Young Guns” and “Old Farts.” Organization, 11(2), 233-250. https://doi.org/10.1177/1350508404030381

Duane Ireland, R., \& Webb, J. W. (2007). A cross-disciplinary exploration of entrepreneurship research. Journal of Management, 33(6), 891-927.

Duening, T. N. (2017). Entrepreneurial identity: Professional virtues moderate attraction and persistence. In T. N. Duening \& M. L. Metzger (Eds.), Entrepreneurial Identity: The Process of Becoming an Entrepreneur (pp. 1-30). Cheltenham, U.K. ; Northampton, MA: Edward Elgar Pub.

Duening, T. N., \& Metzger, M. L. (2017). Entrepreneurial Identity: The Process of Becoming an Entrepreneur. Cheltenham, U.K. ; Northampton, MA: Edward Elgar Publishing.

Eccles, J. (2009). Who am i and what am i going to do with my life? Personal and collective identities as motivators of action. Educational Psychologist, 44(2), 7889. https://doi.org/10.1080/00461520902832368

Emmons, R. A. (1989). The personal striving approach to personality. In Goal concepts in personality and social psychology (pp. 87-126).

Farmer, S. M., Yao, X., \& Kung-Mcintyre, K. (2011). The Behavioral Impact of Entrepreneur Identity Aspiration and Prior Entrepreneurial Experience. Entrepreneurship: Theory and Practice, 35(2), 245-273. https://doi.org/10.1111/j.1540-6520.2009.00358.x

Fauchart, E., \& Gruber, M. (2011). Darwinians, communitarians, and missionaries: The 
role of founder identity in entrepreneurship. Academy of Management Journal, 54(5), 935-957. https://doi.org/10.5465/amj.2009.0211

Fekadu, Z., \& Kraft, P. (2002). Expanding the Theory of Planned Behaviour: The Role of Social Norms and Group Identification. Journal of Health Psychology, 7(1), 3343. https://doi.org/10.1177/1359105302007001650

Field, A. (2005). Discovering statistics using SPSS. London: Sage Publications.

Gollwitzer, P. M. (1999). Implementation intentions: strong effects of simple plans. American Psychologist, 54(7), 493.

Hagger, M. S., \& Chatzisarantis, N. L. D. (2006). Self-identity and the theory of planned behaviour: Between- And within-participants analyses. British Journal of Social Psychology, 45(4), 731-757. https://doi.org/10.1348/014466605X85654

Hair, J. F., Hult, G. T. M., Ringle, C. M., \& Sarstedt, M. (2014). A primer on partial least squares structural equation modeling (PLS-SEM). Thousand Oaks, CA: SAGE Publications, Inc.

Hoang, H., \& Gimeno, J. (2010). Becoming a founder: How founder role identity affects entrepreneurial transitions and persistence in founding. Journal of Business Venturing, 25(1), 41-53.

Holland, A. C., \& Kensinger, E. A. (2010, March). Emotion and autobiographical memory. Physics of Life Reviews.

Hytti, U. (2008). Enterprise Education in Different Cultural Setting and at Different School Levels. In A. Fayolle \& P. Kyrö (Eds.), The dynamics between entrepreneurship, environment and education. Cheltenham, UK: Edward Elgar Publishing Limited. 
Kautonen, T., van Gelderen, M., \& Fink, M. (2015). Robustness of the theory of planned behavior in predicting entrepreneurial intentions and actions.

Entrepreneurship Theory and Practice, 39(3), 655-674.

https://doi.org/10.1111/etap.12056

Kautonen, T., Van Gelderen, M., \& Tornikoski, E. T. (2013). Predicting entrepreneurial behaviour: a test of the theory of planned behaviour. Applied Economics, 45(6), 697-707. https://doi.org/http://dx.doi.org/10.1080/00036846.2011.610750

Kolvereid, L., \& Moen, Ø. (1997). Entrepreneurship among business graduates: does a major in entrepreneurship make a difference? Journal of European Industrial Training, 21(4), 154-160. https://doi.org/10.1108/03090599710171404

Komarkova, I., Conrads, J., \& Collado, A. (2015). Entrepreneurship Competence: An Overview of Existing Concepts, Policies and Initiatives. In-depth case study report. Luxembourg.

Krueger, N. F. (2003). The cognitive psychology of entrepreneurship. In Z. J. Acs \& D. B. Audretsch (Eds.), Handbook of entrepreneurship research: An interdisciplinary survey and introduction (pp. 105-140). London: Kluwer.

Krueger, N. F. (2007). What lies beneath? The experiential essence of entrepreneurial thinking. Entrepreneurship Theory and Practice, 31(1), 123-138.

Krueger, N. F., Reilly, M. D., \& Carsrud, A. L. (2000). Competing models of entrepreneurial intentions. Journal of Business Venturing, 15(5-6), 411-432.

Lent, R. W., Brown, S. D., \& Hackett, G. (1994). Toward a Unifying Social Cognitive Theory of Career and Academic Interest, Choice, and Performance. Journal of Vocational Behavior, 45(1), 79-122. https://doi.org/10.1006/jvbe.1994.1027

Liñán, F., \& Chen, Y. W. (2009). Development and cross-cultural application of a 
specific instrument to measure entrepreneurial intentions. Entrepreneurship: Theory and Practice, 33(3), 593-617. https://doi.org/10.1111/j.1540$6520.2009 .00318 . x$

Liñán, F., \& Rodríguez-Cohard, J. C. (2015). Assessing the stability of graduates' entrepreneurial intention and exploring its predictive capacity. Academia Revista Latinoamericana de Administración, 28(1), 77-98. https://doi.org/doi:10.1108/ARLA-06-2013-0071

Lu, Y., Zhou, T., \& Wang, B. (2009). Exploring Chinese users' acceptance of instant messaging using the theory of planned behavior, the technology acceptance model, and the flow theory. Computers in Human Behavior, 25(1), 29-39. https://doi.org/10.1016/j.chb.2008.06.002

Mets, T., Kozlinska, I., \& Raudsaar, M. (2017). Patterns in entrepreneurial competences as the perceived learning outcomes of entrepreneurship education The case of Estonian HEIs. Industry and Higher Education, 31(1), 23-33. https://doi.org/10.1177/0950422216684061

Mueller, S., \& Anderson, A. R. (2014). Understanding the entrepreneurial learning process and its impact on students' personal development: A European perspective. International Journal of Management Education, 12(3), 500-511.

Nabi, G., Liñán, F., Fayolle, A., Krueger, N. F., \& Walmsley, A. (2017). The impact of entrepreneurship education in higher education: A systematic review and research agenda. Academy of Management Learning \& Education, 16(2), 277-299. https://doi.org/10.5465/amle.2015.0026

Navis, C., \& Glynn, M. (2011). Legitimate distinctiveness and the entrepreneurial identity: Influence on investor judgments of new venture plausibility. Academy of 
Management Review, 36(3), 479-499.

https://doi.org/10.5465/AMR.2011.61031809

Newbery, R., Lean, J., Moizer, J., \& Haddoud, M. (2018). Entrepreneurial identity formation during the initial entrepreneurial experience: The influence of simulation feedback and existing identity. Journal of Business Research, 85, 51-59.

Nigbur, D., Lyons, E., \& Uzzell, D. (2010). Attitudes, norms, identity and environmental behaviour: Using an expanded theory of planned behaviour to predict participation in a kerbside recycling programme. British Journal of Social Psychology, 49(2), 259-284. https://doi.org/10.1348/014466609X449395

Noel, T. W. (2002). Effects of entrepreneurial education on intent to open a business: An exploratory study. Journal of Entrepreneurship Education, 5, 3.

Obschonka, M., Goethner, M., Silbereisen, R. K., \& Cantner, U. (2012). Social identity and the transition to entrepreneurship: The role of group identification with workplace peers. Journal of Vocational Behavior, 80(1), 137-147. Retrieved from http://www.scopus.com/inward/record.url?eid=2-s2.083255185259\&partnerID=40\&md5=2de7408728db09f06c97c69ebfb89ece

Obschonka, M., Silbereisen, R. K., Cantner, U., \& Goethner, M. (2015). Entrepreneurial Self-Identity: Predictors and Effects Within the Theory of Planned Behavior Framework. Journal of Business and Psychology, 30(4), 773-794. https://doi.org/10.1007/s10869-014-9385-2

Pillemer, D. B., Krensky, L., Kleinman, S. N., Goldsmith, L. R., \& White, S. H. (1991). Chapters in Narratives: Evidence From Oral Histories of the First Year in College. Journal of Narrative and Life History, 1(1), 3-14.

Podsakoff, P. M., MacKenzie, S. B., Lee, J., \& Podsakoff, N. P. (2003). Common 
method biases in behavioral research: A critical review of the literature and recommended remedies. Journal of Applied Psychology, 88(5), 879-903.

Ricœur, P. (1990). Soi-même comme un autre. L'Ordre philosophique.

Rise, J., Sheeran, P., \& Hukkelberg, S. (2010). The Role of Self-identity in the Theory of Planned Behavior: A Meta-Analysis. Journal of Applied Social ..., 40(5), 10851105.

Sarasvathy, S. D., \& Venkataraman, S. (2011). Entrepreneurship as Method: Open Questions for an Entrepreneurial Future. Entrepreneurship: Theory and Practice, $35(1), 113-135$.

Savickas, M. L. (2002). Career construction: A developmental Theory of Vocational Behavior. In D. Brown Associates (Ed.), Career choice and development (pp. 149205). San Francisco, CA: Jossey-Bass Publishers.

Schlaegel, C., \& Koenig, M. (2013). Determinants of Entrepreneurial Intent: A MetaAnalytic Test and Integration of Competing Models. Entrepreneurship Theory and Practice, 38(2), 291-332. https://doi.org/10.1111/etap.12087

Schoon, I., \& Duckworth, K. (2012). Who becomes an entrepreneur? Early life experiences as predictors of entrepreneurship. Developmental Psychology, 48(6), 1719-1726. Retrieved from http://www.scopus.com/inward/record.url?eid=2-s2.084874292004\&partnerID=40\&md5=4975c98617f9aa87e25aa0fb78620c6a

Shane, S. A., Locke, E. A., \& Collins, C. J. (2003). Entrepreneurial motivation. Human Resource Management Review, 12(2), 257-279. https://doi.org/10.1016/S10534822(03)00017-2

Shane, S. A., \& Venkataraman, S. (2000). The promise of entrepreneurship as a field of research. Academy of Management Review, 25(1), 217-226. 
Shepherd, D., \& Haynie, J. M. (2009). Family business, identity conflict, and an expedited entrepreneurial process: A process of resolving identity conflict. Entrepreneurship Theory and Practice, 33(6), 1245-1264.

Sideridis, G., Simos, P., Papanicolaou, A., \& Fletcher, J. (2014). Using Structural Equation Modeling to Assess Functional Connectivity in the Brain: Power and Sample Size Considerations. Educational and Psychological Measurement, 74(5), 733-758. https://doi.org/10.1177/0013164414525397

Stets, J., \& Burke, P. (2000). Identity theory and social identity theory. Social Psychology Quarterly, 63(3), 224-237.

Super, D. E. (1963). The definition and measurement of early career behavior: A first formulation. Journal of Counseling \& Development, 41(9), 775-780.

Swail, J., Down, S., \& Kautonen, T. (2014). Examining the effect of “entre-tainment" as a cultural influence on entrepreneurial intentions. International Small Business Journal, 32(8), 859-875. https://doi.org/10.1177/0266242613480193

Swann Jr., W. B., Rentfrow, P. J., \& Guinn, J. S. (2002). Self-verification: The search for coherence. In M. Leary \& J. Tangney (Eds.), Handbook of Self and Identity (p. 367-383.). Guilford Press. https://doi.org/DOI: 10.1037//0003-066X.57.4.297b

Terry, D. J., Hogg, M. A., \& White, K. M. (1999). The theory of planned behavior: Self-identity, social identity, and group norms. British Journal of Social Psychology, 38(3), 225-244.

van Gelderen, M., Kautonen, T., Wincent, J., \& Biniari, M. (2017). Implementation intentions in the entrepreneurial process: concept, empirical findings, and research agenda. Small Business Economics, Online Fir, 1-19.

Williams, H. L., Conway, M. A., \& Cohen, G. (2007). Autobiographical Memory. 
Memory in the Real World. https://doi.org/10.1017/CBO9780511558313 